Nalar: Jurnal Peradaban dan Pemikiran Islam

Vol. 2, No. 2, Desember 2018

\title{
Karakteristik Pendidikan Islam Periode Nabi Muhammad Di Makkah dan Madinah
}

\author{
Agung Ibrahim Setiawan ${ }^{1}$, M Al Qautsar Pratama ${ }^{2}$ \\ ${ }^{1}$ Pascasarjana UIN Sunan Gunung Djati, Bandung \\ ${ }^{2}$ Pascasarjana UIN Sunan Gunung Djati, Bandung \\ 1agungibrahim120@gmail.com,2aqautsar@gmail.com
}

\begin{tabular}{|c|c|}
\hline \multicolumn{2}{|r|}{ Abstrak } \\
\hline Article History & Perkembangan dan transformasi pendidikan Islam tidak terlepas dari peran \\
\hline Received: $13-10-2018$ & Nabi Mubammad saw. sebagai pendiri pondasi yang kuat terhadap \\
\hline Revised: $11-12-2018$ & kehidupan sosial budaya masyarakat Kota Makkah dan Madinah. Corak \\
\hline Accepted: $15-12-2018$ & pendidikan Islam pada periode Nabi Mubammad di Makekah dan \\
\hline Kata Kunci: & Madinah menggambarkan bahwa beliau bukan saja berperan sebagai tokoh \\
\hline Karakteristik, & penyebar Islam saja namun juga sebagai kepala pemerintahan. Nabi \\
\hline Pendidikan Islam, & Mubammad saw. mengajarkan pendidikan Islam pada masyarakat \\
\hline Rasullulab & Makkah dan Madinah dengan metode yang berbeda. Hal ini tidaklah \\
\hline & mengherankan karena tantangan yang di hadapi pada saat proses penerapan \\
\hline & yang berbeda sehingga terciptalah corak yang khas antara keduanya. Selama \\
\hline & kepemimpinan Nabi Mubammad saw. perkembangan pendidikan Islam \\
\hline & berhasil mengubah pola pikir serta tindakan masyarakat Arab menjadi \\
\hline & lebih beradab, beriman kepada Allah, berakblak mulia, cerdas, \\
\hline & berkarakter, dan lain sebagainya. \\
\hline
\end{tabular}

\section{Pendahuluan}

Manusia dan pendidikan adalah dua hal yang sangat berkaitan, pendidikan merupakan suatu proses yang selalu dialami oleh setiap manusia untuk mengembangkan seluruh potensi yang ada dalam diri individu tersebut. Manusia sebagai makhluk yang berdimensi jasmani dan rohani dapat dididik dan dapat pula mendidik. Hal itu dikarenakan Allah menganugerahi manusia alat-alat seperti pendengaran dan penglihatan serta qalb yang digunakan untuk memahami sesuatu. Dengan anugerah yang dimilikinya dituntut untuk semaksimal mungkin mewujudkan tugas dan tujuan hidupnya di dunia ini. Disamping itu, pendidikan merupakan hal yang penting dalam pertumbuhan dan perkembangan secara menyeluruh. Pendidikan senantiasa memberikan andil yang besar dalam membina kemajuan umat serta menciptakan kekuatan yang mendorong ke arah tujuan yang ingin dicapai.

Istilah pendidikan formal dalam Bahasa Inggris dikenal dengan kata education berasal dari kata to educate yaitu mengasuh, mendidik. Dalam Dictionary of Education, arti education adalah sekumpulan dari semua proses yang memungkinkan seseorang mengembangkan kemampuan-kemampuan, sikap-sikap, dan bentuk-bentuk pola perilaku yang bernilai positif di dalam kehidupan sosial tempat dia hidup (Zahra Idris, 1992:2). Istilah education dapat juga berarti proses sosial ketika seseorang dihadapkan pada pengaruh lingkungan yang terpilih dan terkontrol (khususnya lingkungan sosial), kemudian mereka atau peserta didik memperoleh kemampuan sosial dan perkembangan individu secara optimal.

Menurut Ahmad Marimba (1998:23) pendidikan adalah bimbingan atau pimpinan secara sadar oleh pendidik kepada perkembangan jasmani dan rohani yang bersangkutan menuju ke arah terbentuknya kepribadian utama. Dalam sistem pendidikan nasional, dikenal istilah pendidikan sebagai usaha sadar dan terencana dalam menyiapkan peserta didik melalui bimbingan, pengajaran, dan atau persiapan untuk latihan perannya dimasa yang akan datang. 
Nalar: Jurnal Peradaban dan Pemikiran Islam

Vol. 2, No. 2, Desember 2018

Islam sebagai agama yang paling sempurna memiliki tatanan dan pandangan tersendiri tentang konsep pendidikan. Antara Islam dengan pendidikan memiliki hubungan yang sangat erat. Hubungan tersebut bersifat organis-fungsional; dimana pendidikan difungsikan sebagai alat untuk mencapai tujuan keislaman (Hery Noer, 1999). Pendidikan Islam merupakan suatu sistem pendidikan yang teorinya tersusun berdasarkan perintah dari alquran dan hadist. Pada intinya pendidikan dalam pandangan Islam mengutamakan upaya dalam pengembangan seluruh potensi peserta didik seoptimal mungkin. Baik yang menyangkut aspek jasmaniah, rohaniah, akal dan akhlak. Kedatangan Nabi Muhammad saw. membawa ajaran Islam yang telah diturunkan oleh Allah Swt. bertujuan untuk meluruskan dan memacu perkembangan budaya umat manusia. Sebelum Muhammad saw. memulai tugasnya sebagai rasul, yaitu menjalankan pendidikan Islam kepada umatnya, Allah Swt. telah mendidik dan mempersiapakannya untuk melaksanakan tugas tersebut secara sempurna melalui pengalaman, pengenalan serta peran sertanya dalam masyarakat dan lingkungan budaya. Dengan potensi fitrahnya beliau mampu secara sadar menyesuaikan diri dengan masyarakat lingkungannya, tetapi tidak larut sama sekali didalamnya (Haekal, 1972:30-31).

Perjalanan Nabi Muhammad dalam penyampaian dakwah dan pendidikan Islam pada saat itu sangat berat. Beliau melalui proses panjang dan ujian yang berat baik dari dalam dan luar kaumnya sendiri. Namun perjuangan Nabi Muhammad terbayarkan dengan berhasil membangun pondasi kuat agama Islam di tanah Arab. Dalam pembinaan pendidikan Islam Nabi Muhammad melewati beberapa fase penting yaitu: (1) Fase Makkah yakni fase awal pembinaan pendidikan Islam dan (2) Fase Madinah yakni fase penyempurnaan pendidikan Islam. Kedua fase ini memiliki karakter dan keunikan masing-masing sehingga membuat pendidikan Islam memiliki marwah yang kuat sampai sekarang.

\section{Karakteristik Pendidikan Islam di Makkah}

Pendidikan adalah hal yang sangat strategis ketika ingin membangun sebuah peradaban yang maju serta Islami. Dalam perjalanan dakwah Nabi Muhammad saw. menyebarkan Islam dan membangun peradaban tidak terlepas dari pendidikan Rasul kepada sahabat-sahabatnya. Proses pendidikan Islam zaman Rasul dimulai dengan penurunan ajaran Islam kepada baginda Nabi Muhammad dan proses pembudayaannya (masuk dalam kebudayaan manusia sehingga diterima dan menyatu dengan kebudayaan manusia) berlangsung. Masa tersebut berlangsung sejak Muhammad menerima wahyu dan menerima pengangkatan sebagai Rasul, sampai dengan lengkap dan sempurna ajaran Islam menjadi warisan budaya umat Islam. Sepeninggal Rasul masa tersebut berlangsung selama 22 atau 23 tahun, sejak beliau menerima wahyu pertama kali, yaitu 17 Ramadan 13 tahun sebelum hijrah sampai dengan wafatnya pada tanggal 12 Rabiul Awwal 11 Hijrah (Depag, 1978).

Peran Nabi Muhammad dalam proses pendidikan Islam dimulai dari raung lingkup terkecil yakni keluarga dan para sahabatnya. Beliau mendidik umatnya secara bertahap, diawali dengan sembunyi-sembunyi. Mula-mula mengajak istrinya, Khadijah, untuk beriman dan menerima petunjuk-petunjuk Allah, kemudian diikuti oleh anak angkatnya Ali bin Abi Thalib (anak pamannya) dan Zaid bin Haritsah, kemudian dilanjutkan kepada sahabat karibnya yang sudah lama bergaul dengannya Abu Bakar As-Siddiq, yang segera menerima ajakannya. Lalu secara perlahan-lahan ajakan tersebut disampaikan secara meluas namun masih terbatas pada golongan suku Quraisy saja.

Beberapa sumber lain yang terpercaya menyatakan untuk durasi waktu yang dilalui oleh Rasul dalam pendidikan secara sembunyi-sembunyi berjalan sekitar tiga tahun hingga turunnya perintah untuk mengamalkan pendidikan secara terbuka, terang-terangan atau juga 
Nalar: Jurnal Peradaban dan Pemikiran Islam

Vol. 2, No. 2, Desember 2018

sering disebut dakwah secara terang-terangan (Munir, 1992:19). Pendidikan yang dilakukan secara terang-terangan dilakukan olah Nabi saw. setelah adanya jaminan perlindungan dari Allah Swt. kepada Rasul melalui ayat yang turun dalam Q.S. AI-Hijr: 94 dan 95. Alasan lain dakwah secara terbuka dilakukan oleh Rasul, karena mengingat pengikut dan pendukung melalui jumlah sahabat semakin banyak. Maka dengan adanya kekuatan serta dukungan pendidikan secara terang-terangan atau dakwah secara terang-terangan dapat menambah kekuatan lebih besar lagi sehingga para pengikut dan yang masuk Islam semakin bertambah.

Konsep pemikiran pendidikan Islam pada zaman Rasul belum sistematis dan secanggih yang ada seperti zaman modern sekarang ini. Meskipun demikian perhatian umat terhadap ilmu pengetahuan jelas sangat tinggi dan hal ini terwujud sesuai dengan kemungkinan kondisional waktu itu (Nizar, 2001:9). Inti ajaran Nabi Muhammad kepada kaumnya pada awal-awal penyebaran Islam di Makkah adalah ajaran Tauhid. Pelaksanaan pendidikan tauhid tersebut diberikan oleh Nabi Muhammad saw. kepada umatnya dengan cara yang sangat bijaksana dengan menuntut akal pikiran untuk mendapatkan dan menerima pengertian tauhid yang diajarkan dan sekaligus beliau memberikan teladan dan contoh pelaksanaan ajaran tersebut tanpa unsur paksaan.

Nabi Muhammad saw. memperoleh kesadaran dan penghayatan yang mantap tentang ajaran tauhid, yang intisarinya adalah sebagaimana tercermin dalam Surat Al-Fatihah. Pokokpokoknya adalah: (1) Bahwa pencipta alam semesta yang sesungguhnya dialah satu-satunya yang menguasai alam dengan sedemikan rupa; 2) bahwa Allah Swt. telah memberikan nikmat yakni memberikan segala kebutuhan bagi makhluk-Nya, khususnya kepada manusia (3) Bahwa Allah Swt. adalah "raja" hari kemudian, dengan pengertian bahwa segala amal perbuatan manusia sewaktu di dunia ini akan diperhitungkan di sana; (4) Bahwa Allah Swt. adalah yang harus disembah dan satu-satunya; (5) Bahwa Allah Swt. adalah penolong yang sebenarnya, oleh karenanya hanya kepada-Nyalah manusia meminta pertolongan, bukan kepada yang selain-Nya; dan (6) Bahwa Allah Swt. sebenarnya yang membimbing dan memberi petunjuk kepada manusia. (Zuhairini, 2008:23).

Pertama-tama Muhammad saw. dalam rangka memberikan pendidikan tauhid ini, mengajak umatnya untuk melihat sekeliling mereka. Rasul mengajarkan untuk membaca, melihat, memperhatikan, memahami kebesaran Allah Swt. dalam tiap diri manusia. Kemudian secara perlahan Rasul mengubah kebiasaan kaum kafir Quraisy pada saat itu misalnya ketika memulai melakukan pekerjaan tertentu biasanya mereka menyebut nama berhala kemudian diganti dengan bacaan basmalah, mengerjakan sesuatu niatnya karena Allah Swt., mengerjakan pekerjaan dengan harapan mendapatkan pertolongan dan petunjuk dari Allah Swt., tidak melanggar ketentuan Allah Swt. dan dalam segala perbuatan tercermin rasa kasih sayang.

Selain ajaran tauhid, Rasul juga tidak melupakan ajaran tentang alquran. Ada beberapa faktor yang mengharuskan Nabi Muhammad untuk mengajarkan tentang alquran pada masyarakat Makkah secara sempurna. Kondisi masyarakat Arab pada saat itu masih belum bisa membaca dan menulis atau dikenal dengan istilah ummi, hanya segelintir orang saja yang bisa membaca dan menulis. Hal ini membuktikan bahwa baca tulis bukanlah kebiasaaan masyarakat Arab pada waktu itu. Pada awal permulaan Rasul datang ke Makkah hanya beberapa orang saja yang sudah mengenal baca tulis diantaranya: Umar bin Khattab, Ali bin Abu Thalib, Utsman bin Affan, Abu Ubaidah bin Al Jarah, dan lain-lain.

Materi pendidikan yang diberikan adalah materi baca tulis alquran, untuk saat ini dikenal dengan istilah imla' dan iqra'. Dengan diajarkannya materi ini diharapkan agar 
Nalar: Jurnal Peradaban dan Pemikiran Islam

Vol. 2, No. 2, Desember 2018

kebiasaan masyarakat Arab yang sering membaca syair-syair merdu (karena tradisi budaya lisan sangat kental pada masyarakat Arab saat itu) diganti dengan kebiasaan membaca alquran sebagai bacaan yang lebih tinggi nilai sastranya. Kemudian yang tidak kalah penting yakni materi menghafal ayat-ayat alquran. Dengan kebiasaan tradisi lisan masyarakat Arab yang kental, maka mereka dikenal kuat hafalannya. Yang terakhir, materi pemahaman alquransaat ini dikenal dengan materi tafsir alquran-bertujuan untuk meluruskan pola pikir umat Islam yang dipengaruhi pola pikir jahiliah (Iqbal, 2016:6). Selanjutnya, untuk memantapkan hafalan mereka, Rasulullah saw. sering mengadakan ulangan terhadap para sahabatsahabatnya. Nabi saw. menyuruh orang tersebut membaca ayat-ayat alquran di depannya agar mengetahui seberapa mampu dia menghafal ayat-ayat dan jika ada hafalan atau pengucapan yang salah akan langsung diperbaiki oleh Nabi saw. sendiri.

Dalam bukunya yang berjudul Sejarah Pendidikan Islam, Mahmud Yunus (2002:78) menjelaskan bahwa pembinaan pendidikan Islam masa Makkah meliputi: 1) Pendidikan keagamaan yakni dengan ajaran membaca dengan nama Allah Swy. saja, dalam artian Tuhan hanya satu dan tidak bisa dipersekutukan dengan menyembah berhala, karena Allah Swt. Maha Besar dan Maha Pengasih sehingga berhala harus disingkirkan sejauh-jauhnya. 2) Pendidikan yang bersifat pengembangan akhlak dan ilmiah yaitu mempelajari kejadian manusia ketika diciptakan. Allah Swt. akan mengajarkan demikian itu kepada kaum-kaum yang memiliki niat untuk mempelajari dan membahasnya, sedangkan mereka dahulu belum mengetahuinya. Untuk mempelajari itu harus banyak membaca dan memahami. 3) Pendidikan akhlak dan budi pekerti, Nabi Muhammad saw. mengajar sahabatnya agar berakhlak baik sesuai dengan ajaran tauhid. 4) Pendidikan jasmani (kesehatan), yaitu mementingkan kebersihan pakaian, badan dan tempat tinggal.

\section{Karakterisktik Pendidikan Islam di Madinah}

Periode Madinah merupakan awal dibangunnya pondasi kekuatan politik Islam. Seruan ajaran Islam yang berkaitan dengan kehidupan masyarakat banyak turun di kota Madinah. Posisi Nabi saw. tidak hanya berperan sebagai tokoh agama saja tetapi juga sebagai kepala pemerintahan. Nabi Muhammad saw. sangat dihormati dan dihargai oleh sesama muslim bahkan mereka yang non-muslim. Untuk melaksanakan fungsi utamanya sebagai pendidik, Rasulullah saw. telah melakukan serangkaian kebijakan yang amat strategis dalam memajukan sistem pendidikan Islam di Madinah.

Kedatangan Nabi saw. bersama kaum muslimin dari Makkah disambut oleh penduduk Madinah dengan gembira dan penuh rasa persaudaraan. Maka Islam mendapat lingkungan baru yang bebas ancaman dari kaum kafir Quraisy Makkah, lingkungan yang memungkinkan Nabi Muhammad saw. meneruskan dakwahnya, menyampaikan ajaran Islam dan menyebarkannya dalam kehidupan sehari-hari. Walaupun demikian, Rasul banyak mendapatkan tantangan ketika menyebarkan ajaran Islam di Madinah. Dimana kondisi masyarakat Madinah yang terdiri dari berbagai macam latar kehidupan yang berbeda-beda yaitu mereka yang berasal dari Makkah yang kemudian disebut dengan nama kaum Mujabirin, dan mereka yang merupakan penduduk asli Madinah yang kemudian disebut kaum Anshar (Zuhairini, 2008 :23).

Kenyataan lain yang dihadapi Rasulullah saw. adalah bahwa masyarakat kaum muslimin yang baru di Madinah tersebut, berhadapan atau tinggal bersama dengan 
Nalar: Jurnal Peradaban dan Pemikiran Islam

Vol. 2, No. 2, Desember 2018

masyarakat suku bangsa Arab lainnya yang belum masuk Islam dan masyarakat kaum Yahudi yang sejak dari awal menjadi penduduk Madinah.

Melihat kenyataan tersebut, Nabi Muhammad saw. mulai mengatur segenap potensi yang ada pada lingkungan masyarakat Madinah yang bisa dikatakan belum tertata dengan baik. Rasul memulai memecahkan masalah yang ada dengan kekuatan dan potensi yang ada agar kedepannya mampu menciptakan masyarakat yang mampu menghadapi persoalan hidup dan tantangan yang berasal dari luar dengan menggunakan kekuatan sendiri.

Jika pada periode Makkah, corak pokok pembinaan pendidikan Islam lebih mengarah pada pendidikan tauhid (dalam arti yang luas), maka berbeda dengan periode Madinah. Pola yang diterapkan di Madinah lebih menekankan kepada pola pendidikan sosial-politik. Tetapi kedua ciri tersebut bukanlah dua hal yang bisa dipisahkan satu sama lain. Kalau pendidikan Islam di Makkah lebih menitikberatkan pada penanaman nilai-nilai tauhid ke dalam jiwa setiap individu Muslim. Sedangkan pembinaan pendidikan Islam di Madinah pada hakikatnya merupakan kelanjutan dari pendidikan tauhid di Makkah, yaitu pembinaan bidang pendidikan sosial-politik agar dijiwai ajaran tauhid, sehingga akhirnya tingkah laku sosial politiknya merupakan cermin dan pantulan sinar tauhid tersebut.

Pada prosesnya, kota Madinah disulap oleh Nabi Muhammad saw. menjadi kota yang maju dan berkembang pesat. Bahkan bisa dikatakan kota Madinah pada saat itu menjadi kota yang dibangun dari prinsip-prinsip yang berasal dari dimensi wahyu alquran dan sains yang termuat didalamnya. Madinah ditata oleh Nabi saw. sebagai wilayah yang menentukan bagi ruang dan tempat umat Islam untuk hidup, bekerja, dan beribadah. Maka wajar dalam waktu yang relatif singkat telah terjadi pergeseran mental penduduk Madinah, yang dulunya selalu membanggakan fanatisme kesukuan menjadi sikap mengutamakan lingkungan hidupnya (almuwathin wa al-ard) atas dasar nilai-nilai agama. Pembangunan dan tata letak wilayah Madinah dibuat sedemikian rupa agar menjadi pemukiman yang asri baik dalam dimensi material maupun spiritual untuk ukuran masyarakat pada saat itu (Ajid Thohir, 2014:253).

Berbeda dengan di Makkah yang menggunakan rumah sebagai tempat untuk berdakwah, di Madinah masjid dijadikan pusat pengajaran Islam kepada seluruh lapisan masyarakat. Masjid dijadikan pusat kegiatan Nabi Muhammad saw. bersama kaum muslimin, untuk secara bersama-sama membina masyarakat baru. Masyarakat yang disinari oleh tauhid dan mencerminkan persatuan dan kesatuan umat. Bangunan masjid terletak di tengah-tengah permukiman penduduk (jauf al-Madinab). Salah satu sudut masjid tersebut dijadikan sebagai tempat kediaman beliau, dengan dua kamar untuk masing-masing kedua istrinya. Ternyata, bangunan masjid begitu efektif sebagai wadah pertemuan bagi anggota masyarakat. Sebelum Islam masuk ke Madinah tempat ini dijadikan sebagai tempat pertemuan namun fungsinya sebagai kedai malam tempat hiburan saja. Setiap waktu, kaum muslimin terus bertemu minimal lima kali sehari semalam untuk kepentingan ibadah, belajar agama, bermusyawarah dan sebagainya (Ajid Thohir, 2014:276).

Perkembangan materi dan tujuan pendidikan Islam di Madinah semakin luas dibandingkan pendidikan Islam di Makkah. Hal ini diiringi dengan perkembangan masyarakat 
Nalar: Jurnal Peradaban dan Pemikiran Islam

Vol. 2, No. 2, Desember 2018

Islam dan petunjuk-petunjuk Allah. Tujuan pendidikan Islam bukan hanya difokuskan untuk membentuk pribadi kader Islam, namun masyarakat Madinah pada saat itu juga dibekali dengan pendidikan tauhid, akhlak, amal ibadah, kehidupan sosial kemasyarakatan dan keagamaan, ekonomi, kesehatan, bahkan kehidupan bernegara (Abudin, 2011:77-78).

Pada saat di Madinah, materi pendidikan yang diberikan cakupannya lebih kompleks dibandingkan dengan materi pendidikan fase Makkah. Materi pendidikan Islam itu antara lain: 1) Pendidikan persaudaraan sesama umat atau meningkatkan ukhuwah. Pada proses pelaksanaan pendidikan ukhuwah ini, Rasul saw. memfokuskan pada struktur kekeluargaan yang ada pada masa itu. Dalam usaha mempersatukan keluarga itu Nabi Muhammad saw. berusaha untuk mengikatnya menjadi satu kesatuan yang kuat. Masyarakat Madinah dipersaudarakan karena Allah Swt. bukan karena yang lain. Sesuai dengan Piagam Madinah bahwa antara orang yang beriman tidak boleh membiarkan saudaranya menanggung beban hidup dan utang yang berat di antara sesama manusia. 2) Pendidikan kesejahteraan sosial. Dalam hal ini Nabi Muhammad saw. selalu memberikan motivasi untuk selalu semangat mencari nafkah yang halal. Beliau mengarahkan kaum Mubajirin yang telah dipersaudarakan dengan kaum Anshar agar bekerjasama bahu membahu dalam mewujudkan masyarakat yang sejahtera. 3) Pendidikan kesejahteraan keluarga kaum kerabat. Nabi Muhammad saw. selalu berpesan agar memiliki ikatan kekerabatan yang solid satu sama lain. Selain itu, Rasul saw. berusaha untuk memperkenalkan dan sekaligus menerapkan sistem kekerabatan yang berdasarkan taqwa kepada Allah Swt. 4) Pendidikan Pertahanan dan Keamanan. Hal ini sangat penting bagi suatu peradaban yang sudah berdiri kokoh karena dengan adanya sistem keamanan dan pertahanan masyarakat pada saat itu mampu membentengi diri dari serangan musuh dari luar dengan membentuk pasukan dan tentara keamanan yang selalu siaga dalam menghadapi serangan musuh (Kamaruzzaman, 2007).

\section{Kesimpulan}

Jadi, antara pendidikan Islam yang diajarkan oleh Nabi Muhammad saw. di Makkah dan Madinah memiliki karakter, pola, dan perkembangannya yang berbeda. Jika di Makkah lebih kepada pengajaran pendidikan Islam yang menekankan pada pemahaman tauhid dan pengajaran alquran, sedangkan di Madinah lebih meluas cakupannya yakni selain diajarkan tauhid dan alquran, masyarakat Madinah dibekali dengan pendidikan akhlak, amal ibadah, kehidupan sosial kemasyarakatan dan keagamaan, ekonomi, kesehatan, bahkan kehidupan bernegara. Dalam proses perjalanannya Rasulullah saw. menerapkan pendidikan Islam disesuaikan dengan kondisi sosial masyarakat pada saat itu sehingga pendidikan Islam cepat diterima dan diamalkan oleh masyarakat Makkah dan Madinah. 
Nalar: Jurnal Peradaban dan Pemikiran Islam

Vol. 2, No. 2, Desember 2018

\section{DAFTAR PUSTAKA}

Al-Ghadban. 1992. Syaikh Munir Mubammad, Manbaj Haraki Strategi Pergerakan dan Perjuangan Politik dalam Sirah Nabi SAW., Jakarta: Rabbani Press.

Aly, Heri Noer. 1999. Imu Pendidikan Islam, Jakarta: Logos Wacana Ilmu.

D. Marimba, Ahmad. 1998. Pengantar Filsafat Pendidikan, Bandung: Al Ma'arif.

Departemen Agama RI, Al-Quran dan Terjemahannya, Muqadimah.

Husain Haekal, Muhammad. 1972. Sejarah Hidup Nabi Mubammad, Jakarta: Tintamas.

Idris, Zahara. 1992. Pengantar Pendidikan, Jakarta: Grasindo.

Iqbal, Muhammad. 2015. Pola Pendidikan Islam Pada Periode Rasullulah, dalam JIPS $A, V$ ol. 15. No. 17. November 2015.

Kamaruzzaman, 2007. Pola Pendidikan Islam Pada Periode Rasullulah: Makkah dan Madinah. Jakarta: Kencana Prenada Media Grup.

Nata, Abuddin. 2011. Sejarab Pendidikan Islam, Jakarta: Kencana.

Nizar, Samsul. 2001. Pengantar Dasar-dasar Pemikiran Pendidikan Islam, Jakarta: Gaya Media Pratama.

Tafsir, Ahmad. 1994. Ilmu Pendidikan dalam Perspektif Islam, Bandung: Remaja Rosdakarya.

Thohir, Ajid. 2014. Sirah Nabawiyah: Nabi Muhammad dalam Kajian Sosial Humianiora, Bandung: Penerbit Marja.

Zuhairini, dkk. 2008. Sejarah Pendidikan Islam, Jakarta: Bumi Aksara. 